\title{
Cultural Traditions And Economics Dinamyes Of The Songket Weaving Craftmen In Palembang
}

\author{
Gayung Kasuma ${ }^{1}$, Rizki Andini ${ }^{2}$,Ikhsan Rosyid M Anwari ${ }^{3}$ \\ \{1 gayung-k@fib.unair.ac.id, ${ }^{2}$ rizki-a@fib.unair.ac.id, ${ }^{3}$ ikhsan-r-m-a@fib.unair.ac.id\} \\ ${ }^{1,2,3}$ Airlangga University
}

\begin{abstract}
Local wisdom in the weaving tradition is an identity strengthening which is supported by the inheritance of the traditional arts from generation to generation. Songketfabric weaving is the creativity of local people in the fulfillment of traditional clothing, as well as social functions, symbols and icons of the city. The ethnic identity, social function, and symbolic value make the weaving tradition can still continue until now. Inheritance of this tradition is maintained through self-taught methods from family experience. This pattern illustrates that the interests and creativity of the community continue to develop until now, regardless of aspects of economic importance. Palembang Songket weaving tradition is a long process in the culture of Palembang society. Since the end of the Palembang Darussalam Sultanate until the Dutch ruled Palembang in 1821, the term ofSongket did not seem to be generally accepted. In the second half of the 19th century many noblemen or known as 'priyayi'were forced to try to make a living by earning Songket weaving in the house, without having to sacrifice the dignity their nobility in public. This condition then lead the creation of Songket for public, even the craftsmen are in some suburb areas of Palembang.
\end{abstract}

Keywords: identity; local wisdom; cultural traditon; Palembang Songket weaving craftmen

\section{Introduction}

Palembang is the capital city of South Sumatra Province.Based on the clans, the people of Palembang consist of two groups: the descendants of the kings or dignitaries of the former Palembang kingdom consisting of"priyayi" or "Wong Jeroo" (the insiders) and ordinary groups (Wong Jabo) or people who were not part of palace family and livedoutside the palace of Palembang Sultanate.

Social interaction and communication are carried out in local languages as part of selfidentity. The language used is Palembang, which is a blend of Malay and Javanese. The combination of Malay-Javanese culture has a distinctive language that is the language of the palace and common languages. The Keraton language is the eastern coast of Java, which is used in the environment of the palace called the Palembang polite language (bebaso), its use began to disappear since the fall of the Sultanate of Palembang by the Dutch. The common language used by the public is better known as Palembang (Malay-Palembang) as an 
intermediary language in most parts of Southern Sumatra. [1]This way of communication leads people to interact with each other, thus bringing significant developments in various traditions.

Interestingly, a note compiled in Palembang in the early 18th century mentions that the harbor master, known as the syahbandar, (official port head) is believed as "the father and mother of traders."[2] Palembang Harbor was visited by many commercialships, especially from Java, Madura, Bali and Sulawesi around the 18th century which usually carried rice, salt, and clothing. Palembang is an important kingdom and its river is one of the largest rivers on the island of Sumatra. Based on its geographical features, Palembang city is located in a swampy plain. The lower part of the Palembang area towards the beach is described as a place that is easily flooded. Therefore, this area is not suitable for agriculture, except for a few part only. The language in the palace circles is smooth Javanese and mixed with foreign expressions. However, when they talk to strangers, they use Malay by saying the letter (o) for the letter (a) at the end of the word. Palembang folk language is a mixture of Malay and Javanese. Furthermore, the development of Islam has spread throughout the Kingdom of Palembang and beyond.[3]

Along with the development, the weaving tradition becomes the cultural heritages. The history and tradition of Palembang Songket weaving is a long process of cultural heritage of the Palembang people through self-taught learning models. Since the end of the Palembang Darussalam Sultanate until the Dutch taking over Palembang in 1821, the term ofsongket also did not seem to be generally accepted. There is only cloth embroidered with gold. In the book, Sevenhoven explains: "Priyayi in general live in their homes in very poor conditions. From the first level, they have some beautiful sheets embroidered with gold thread or decorated with flowers and pictures of gold, some clothes decorated with lace and made of other expensive materials, ... "[4] [5]

Historically, the beautiful gold embroidered linen fabric has developed progressively when some people began make Songket cloth until now. According to several informants, during the weaving process, there are three main types of skills that must be possessed by a craftsman;those arenyukit, nyongket, and bedandan. Nyukit is the initial design of a pattern that will determine the motif of a songket. Nyongket is the process of making woven fabric by slipping threads with threads interspersed with special threads to display predetermined motifs from the beginning until the process is finished. Bedandan is a skill to repair equipment instruments in weaving songket fabric that is damaged or does not function properly. However, behind all that there are many problems occured between continuing family traditions and economic interests.

\section{Research Method}

The research source was obtained from the results of a literature review on Songket weaving. The data was obtained at government offices in Palembang. In-depth interviews with resource persons in the Palembang Songket weaving craftsmen community. Observe the activities of the local community and make direct observations in the field. Data is verified and analyzed using the historical method approach. Collecting research resources. Source criticism through selection, interpretation of selected data and analysis.[6] 


\section{Results And Discussion}

The human factor is very dominant in the process of the Palembang SongketWeaving craft. Like a tradition, the learning process and the desire to continue the tradition are very strong. Unfortunately, Palembang peopleas the heirs of Palembang Songketweaving craft culture did not succeed in leaving this craft in writing. As the result, the relay of cultural inheritance can only be done verbally and imitating behavior. [7] Therefore, not all people of Palembang traditionally carry out this activity; if their ancestors did not carry out the Weaving Songket Weaving Craft in Palembangthen the inheritance of this tradition would not occur. So genealogically, the human factor is very important, especially fot those who have to hand the weaving talents and traditions down from generation to generation in one family.

This uniqueness has settled in a society that has the potential to change and move to follow the complexity of the cultural flow. Thus, if culture is a precipitate of human activity and work, [8][9] then the Weaving Songket craft is one of human works that settles and becomes an element of tradition in Palembang society. Therefore, the reflection is pictured in the adaptation patterns of the community in surviving, producing, enhancing their creativity and marketing strategies for the results of the Songket woven fabric.

Besides humans, the natural factorbecomes an important part as an instrument that supports the process of someone starting the fabric making of SongketWeaving. Natural silk or filament silk as one of the raw materials for textiles is currently being developed in South Sumatra, especially in the city of PagarAlam, ranging from mulberry planting, silkwormraising to the process of reeling / spinning yarn. Natural silk threads are not so widely used because the filament is easily tangled during the degumming process, the coloring process, and the weaving process

In the process of Songket fabric making, the yarn used is generally colored and does not need to be starched anymore, because after weaving the fabric is usually directly used without washing process that can damage the gold thread. Therefore, in order to make the natural silk threads do not wrinkle or decompose during the degumming process, the coloring process, and the twisting process in which two or more strands of yarn are joined together, a twistare added so that the yarn is resistant to friction or pull.

Furthermore, the meaning of thesongket term is officially not defined yet until today. However, several sources provide explanations that lead to the grammatical understanding. Songket, according to this source, comes from the words of disongsong and teket. The word teket in ancient Palembang word means embroidery. The word refers to the weaving process, where the insertion of yarn and other supporting equipment into the longsen is carried out in a way that is received or welcomed. Thus, songket means cloth that is made and embroidered.

The golden threads in the old songket, which are hundreds of years old and usually cannot be worn anymore as clothes, are broken down one by one. Furthermore, with silk feed, this golden thread is woven back into a "new" songket. The traditional techniques namely traditional dyes (dyes or kesumbo drugs) are used in the process of dyeing the yarn. The material used in producing songket consists of yarn, dyes and water. The yarn are imported from from China, India, Taiwan and Japan. The dyes purchased can be reprocessed, so that natural dyes found in the Palembang area to get a certain color effect are known as kesumbo.

The tradition of expertise inheritance in Palembang weavingSongket crafts occurs from one family who owns a craft center business and indirectlyhand it down to the family, especially girls. [10] So far, the tradition of this weavingSongketis done by the women in majority. Social capital as a component of adaptive capacity is suggested by their family use natural, social, and habitual. [11] 
Historically, this fact is supported by the existence of certain regional centers that produce the Palembang Songketweaving from the past to the present. Their ancestors had taught the process through daily behavior with the habit of weaving the Songket. Gradually, this process was imitated by their children and grandchildren. It does not require special expertise in this case, only a need of patience and tenacity to sit long in front of the loom. Craftsmen are required to be able to arrange threads with certain patterns. The loom is used manually. So far, the equipment is better known as ATBM (Alat Tenun Bukan Mesin or Non-Machine Weaving Equipment) or ATKT (Alat Tenun Kerajianan Tanganor Hand Weaving Equipment).

Based on some interview sources, there are a small number of men who also do this songket weaving activity. However, this is not his main occupation, but only as a side job. [12] [13] Actually, this manufacturing process is very easy to imitate; therefore, this inheritance process does not really has significant difficulties, especially in term of skills or expertise. It emphasizes the accuracy technique of arranging threads and motif patterns on songket weaving. Each craftsman raises its own character and characteristics in producing woven.

The economic dynamics faced by home craftsmen deals with the price of their products. Some of them are tied to the need for raw materials to make Songket woven fabrics. Some shops in 16 IlirPalembang traditional marketthat provide raw materials, use a barter system by exchanging the results of songket weaving made by the craftsmen. Difference in price of raw materials and the selling price of songket woven cloth are given in the form of money. Yusmani, one of the craftsmen, said that the routine shopping and exchanging raw materials, is carried out approximately 2 to 3 months. It depends on the results of weaving that is done; it can also be accelerated due to the demands of an urgent kitchen need. [14] [15] Thus, the craftsmen do not have the power to set high selling prices because they are urged by household needs. The same thing is faced by business owners who employ several songket weaving craftsmen. According toCekRomlah's, if they are guided by a well-known business group, they do not have the freedom to sell and determine the price of songketwoven fabric, because the production is produced in the name of the famous business owner. Of course it is detrimental in terms of the economy and the copyright issue.[16]

\section{Conclusion}

Palembang Songket can be said to have its own uniqueness. The uniqueness is mainly found in the design. All of the uniqueness, especially the philosophical values it contains, make Palembang songket different from the variety of woven fabrics from other regions. Of all these things, of course it is not excessive if there are opinions that say that Palembang songket is a high-value cultural product. The traditions carried out by the craftsmen are part of cultural transfer through the processof seeing, understanding, understanding and doing it. Therefore, the reflection is pictured in the adaptation patterns of the community in surviving, producing, enhancing their creativity as well as marketing strategies for Songket woven products. In fact, its local identity and wisdom strengtheningare not comparable with the inheritance of tradition and economic interests.

Cultural identity in the form of a local traditions legacy in the past that supports the creative industries of the WeavingSongket craftsmen is inseparable from its understanding routines in the daily context of the families of theSongket weaving craftsmen themselves. Referring to the term used byDediIrwanto, [17] the people of Palembang city through the ideological construction of the colonial period and the search for identity in the transition 
period has brought a flow of change, occurring when there are "fights" between the natives and migrants. One choice of work as a Songket weaver is part of the inheritance of cultural traditions within a family in addition to the alternatives to meet the economic needs of the community. According to Dare (2009), local people build their wealth of knowledge through cognitive mapping and validation. [18][19]

\section{References}

[1] N. Syafidin, Perkawinan Wong Palembang Menurut Tatanan Adat. Palembang: PEMDA Sumsel, 2006.

[2] B. W. Andaya, Hidup Bersaudara Sumatera Tenggara Pada Abad XVII dan XVIII. Yogyakarta: Ombak, 2016.

[3] W. Marsden, Sejarah Sumatera. Jakarta: Komunitas Bambu, 2008.

[4] J. L. V. Sevenhoven, Lukisan Tentang Ibukota Palembang, terj. Sugarda Purbakawatja. Jakarta: Bhratara, 1971.

[5] Y. Syarofie, Songket Palembang; Nilai Filosofis, Jejak Sejarah dan Tradisi. Palembang: PEMDA Sumsel, 2007.

[6] G. Garraghan S.J, A Guide to Historical Method. New York: Fordham University Press, 1957.

[7] Y. Munaf, "Kerajinan Songket Palembang," Ranah Seni, J. Seni Desain, vol. 03, no. 02, p. 613, 2010.

[8] C. A. van Peursen, Strategi Kebudyaan. Jakarta: Kanisius, 1988.

[9] Y. Syarofie, Songket Palembang; Nilai Filosofis, Jejak Sejarah dan Tradisi. Palembang: PEMDA Sumsel, 2007.

[10] A. R. R. Brown, Structure and Function in Primitive Society. New York: The Free Press, 1965.

[11] B. J. Colombi and C. L. Smith, "Adaptive Capacity as Cultural Practice," Ecol. Soc., vol. 17, no. 4, 2012.

[12] "Interview with Idris 55th, 12 Juni 2018," Palembang, 2018.

[13] "Interview with Fadilah, 57th, tanggal 14 Maret 2018," Palembang, 2018.

[14] "Interview with Yusmani, 58th, tanggal 11 Juni 2018," Palembang, 2018.

[15] "Interview with Piah, 45th,tanggal 5 Juli 2019," Palembang, 2019.

[16] "Interview with Cek Romlah, 62th, 12 Juni 2018 dan 3 Juli 2019," Palembang.

[17] D. Irwanto, Venesia Dari Timur: Memaknai Produksi dan Reproduksi Simbolik Kota Palembang Dari Kolonial sampai Pascakolonial. Yogyakarta: Ombak, 2011.

[18] K. O. D. Dare, "Situating local knowledge within development agenda Some reflections," Consilience, vol. 2, no. 2, pp. 1-23, 2009.

[19] K. Saddhono, S. T, Widodo, M. T. Al Makmun, and M. Tozu, "The study of philosophical meaning of batik and kimono motifs to foster collaborative creative industry." Asian Soc. Sci. vol. 10 no. 9 pp 52-61, 2014 